\title{
Nitrogen-Fertilized Systems of Maize Intercropped With Tropical Grasses for Enhanced Yields and Estimated Land Use and Meat Production
}

\section{OPEN ACCESS}

Edited by:

Paulo Mazzafera,

Campinas State University, Brazil

Reviewed by:

Davey Jones,

Bangor University, United Kingdom

Muhammad Ali Raza,

Sichuan Agricultural University, China

*Correspondence:

Carlos A. C. Crusciol

carlos.crusciol@unesp.br

Letusa Momesso

letusamomesso@gmail.com

${ }^{\dagger}$ Present address:

Emerson Borghi,

EMBRAPA, Brazilian Agricultural

Research Corporation, Corn and

Sorghum Research Center,

Sete Lagoas, Brazil

Specialty section:

This article was submitted to

Crop Biology and Sustainability,

a section of the journal

Frontiers in Sustainable Food Systems

Received: 23 March 2020

Accepted: 09 October 2020

Published: 05 November 2020

Citation:

Crusciol CAC, Mateus GP, Momesso L, Pariz CM, Castilhos AM, Calonego JC, Borghi E, Costa C, Franzluebbers AJ and Cantarella $H$ (2020) Nitrogen-Fertilized Systems of

Maize Intercropped With Tropical Grasses for Enhanced Yields and

Estimated Land Use and Meat

Production.

Front. Sustain. Food Syst. 4:544853. doi: 10.3389/fsufs. 2020.544853

\begin{abstract}
Carlos A. C. Crusciol ${ }^{1 *}$, Gustavo P. Mateus ${ }^{2}$, Letusa Momesso ${ }^{1,3 *}$, Cristiano M. Pariz ${ }^{4}$, André M. Castilhos ${ }^{4}$, Juliano C. Calonego ${ }^{1}$, Emerson Borghi ${ }^{5 t}$, Ciniro Costa ${ }^{4}$, Alan J. Franzluebbers ${ }^{6}$ and Heitor Cantarella ${ }^{7}$

'Department of Crop Science, College of Agricultural Science, UNESP, São Paulo State University, Botucatu, Brazil, 2 Department of Development Decentralization, Agência Paulista de Tecnologia dos Agronegócios, São Paulo Agency of Agribusiness Technology, Andradina, Brazil, ${ }^{3}$ Department of Microbial Ecology, NIOO-KNAW, Netherlands Institute of Ecology, Wageningen, Netherlands, ${ }^{4}$ Department of Animal Nutrition and Breeding, School of Veterinary Medicine and Animal Science, UNESP, São Paulo State University, Botucatu, Brazil, ${ }^{5}$ College of Agricultural Science, São Paulo State University, Botucatu, Brazil, ${ }^{6}$ USDA, Agricultural Research Service, NCSU Campus, Raleigh, NC, United States, ${ }^{7}$ IAC, Instituto Agronômico de Campinas, Soils and Environmental Resources Center, Campinas, Brazil
\end{abstract}

Intercropping grain with forage crops bridges the gap between agriculture and sustainability. In tropical regions, forage grasses are increasingly being adopted as winter pasture intercropped and in rotation with maize to maximize food production. However, current recommendations for nitrogen $(\mathrm{N})$ fertilizer application are based on monocropped maize (Zea mays), and the best $\mathrm{N}$ management approach for intercropping systems remains unclear. A field experiment was carried out in three growing seasons with three intercropping systems [monoculture maize, intercropped with palisadegrass (Urochloa brizantha), and intercropped with guineagrass (Megathyrus maximus)] combined with six different split applications of $\mathrm{N}$ to maize $(0-0,100-0,70-30$, 50-50, 30-70, and 0-100 kg N ha ${ }^{-1}$ at seeding-sidedressing) with four replicates. We measured dry matter (DM) and accumulated $\mathrm{N}$ in maize and forage grasses, as well as maize production components and yields. Additionally, land equivalent ratio, relative crowding coefficient, aggressivity of maize with forage grasses, forage crude protein (CP) concentration, estimated animal stocking rate, and estimated meat production and economic outcomes. Greatest maize yield was $8.7 \mathrm{Mg} \mathrm{ha}^{-1}$ for monocropped maize. However, favorable maize yield was also obtained in intercropping systems. Although no difference was observed between intercropping systems, applying all $\mathrm{N}$ at sidedressing of maize negatively affected maize and forage yields and, consequently, land use and economic evaluation. For both intercropping systems, estimated meat and land use were 114 and $10 \%$ higher when $\mathrm{N}$ fertilizer was applied than the control $\left(0-0 \mathrm{~kg} \mathrm{~N} \mathrm{ha}^{-1}\right)$, on average. Maize-forage grass intercropping is a viable alternative production system for improving yields and land use. In addition, estimated meat production and revenue can be enhanced with palisadegrass or guineagrass. At least half of the $\mathrm{N}$ fertilizer must be applied early in the growing season of maize to maximize production of the entire system.

Keywords: Brachiaria brizantha, Megathyrsus maximus, Zea mays L., tropical agriculture, intercropping grasses, no-tillage system 


\section{INTRODUCTION}

Intensive use of agricultural land is a global concern. The challenge of agricultural systems is to increase crop and food production, while reducing land use. A new commercial practice of intercropping grain and forage crops bridges the gap between agriculture and environmental sustainability (Mateus et al., 2016; Martin-Guay et al., 2018). Additionally, fertilizer management, such as $\mathrm{N}$ application, benefits these intercropping systems by enhancing yields and minimizing plant competition. However, the appropriate time for $\mathrm{N}$ management in intercropping systems remains incompletely studied. A new approach of maize-grass intercropping systems for crop and meat production has been suggested since intercropping with forages results in yield improvements and in satisfactory socioeconomic outcomes for integrated crop-livestock systems (ICLS) with a no-tillage system (NTS) (Derpsch and Friedrich, 2009; Himmelstein et al., 2017; Pariz et al., 2017a).

Intercropping tropical forages and cash crops is an alternative for farmers to develop temporary pasture using ICLS combined with NTS (Pariz et al., 2017b). With ICLS, food production potential (meat and grains) can be enhanced on the same land area and thus limit deforestation of new agricultural areas (Moraes et al., 2019). In the tropical region, forage grasses are being increasingly adopted in ICLS under NTS for winter pasture to maximize system production (Crusciol et al., 2015; Pariz et al., 2016, 2017a,b). Palisadegrass [Urochloa brizantha (=syn. Brachiaria)] and guineagrass [Megathyrsus maximus (=syn. Panicum maximum)] has been suitable species for intercropping with cash crops (Costa et al., 2015; Mateus et al., 2016; Pariz et al., 2016). Importantly, this strategy of intercropping forages with grain crops enhances the success of forage production in the dry winter season with low and irregular rainfall (Borghi et al., 2013a). Therefore, more reliable forage biomass production raises the protein concentration and potential meat production by animals grazing fodder in ICLS (Crusciol et al., 2012, 2014; Moraes et al., 2019).

Maize-forage grass intercropping has increased as cultivation practice (Sulc and Tracy, 2007; Tracy and Zhang, 2008; Moraes et al., 2019). Intercropping grasses with maize improves soil quality and increases soil organic $\mathrm{C}$ and $\mathrm{N}$ stocks by promoting deep root systems and better nutrient retention compared with monocrops (Costa et al., 2012, 2015; Cong et al., 2015). Because of the potential of cycling $\mathrm{N}$ from soil by plant $\mathrm{N}$ uptake and consequent high straw decomposition, providing diversity of residues, and nutrient back to the soil (Pariz et al., 2017b; MartinGuay et al., 2018). However, maize and grass may compete for $\mathrm{N}$ sources at the vegetative growth stages in intercropping systems, since grasses can immobilize $\mathrm{N}$ by microbial processes and increase the dependence on $\mathrm{N}$ fertilizer for crop yields (Pariz et al., 2011; Mateus et al., 2016), especially during the first several years of cultivation in NTS with accumulation of soil organic matter. In addition, $\mathrm{N}$ demand by maize is high during early- to mid-season growth (Anghinoni, 2007; Borghi et al., 2014; Garcia et al., 2016).

Current recommendations for $\mathrm{N}$ application are based on maize monocropping (Cantarella et al., 1997), however, the
$\mathrm{N}$ fertilizer recommendations for intercropping systems with maize-grasses have not been adequately studied for crop yields and meat production. Although agricultural models of possible $\mathrm{N}$ fertilizer application in ICLS based on $\mathrm{N}$ rates have been documented (Borghi et al., 2014; Mateus et al., 2020), there is a lack of information on how to achieve maximum potential of intercropping systems through fertilizer management. Nitrogen recommendations need to be tested based on suitable application timing. Managing $\mathrm{N}$ fertilizer in intercropping systems by dividing the rate into two application timings may promote greater $\mathrm{N}$ uptake and yield of maize, as has been shown for intercropped sorghum and forage grasses (Mateus et al., 2016). In addition, split $\mathrm{N}$ application may provide sufficient $\mathrm{N}$ for the high $\mathrm{N}$ demand of maize and forage, thus tightening the $\mathrm{N}$ cycle and minimizing environmental pollution.

While studies have shown reduction of soil erosion and degradation, stimulation of root growth and increase of forage yields in intercropping systems in relation to sole-cropping systems (Pariz et al., 2017b; Moraes et al., 2019), the potential food supply for livestock and farmers' profitability do not appear to have been investigated in maize-grasses intercropping systems with proper $\mathrm{N}$ management. The aim of this study was to evaluate the effects of split $\mathrm{N}$ application to maizeforage intercropping systems on crop yield, land equivalent ratio (LER), crop competition, estimated meat, and overall system revenue. We hypothesized that $\mathrm{N}$ management applied at maize seeding and at sidedressing of maize at $\mathrm{V}_{5}$ growth stage, i.e., the initiation of maize ear development, would (i) increase yields of maize and forage grasses, (ii) increase efficiency land use and estimated meat production, (iii) decrease competition between intercropped crops, and (iv) provide high revenue. To test these hypotheses, we used the same $\mathrm{N}$ rate of $100 \mathrm{~kg} \mathrm{ha}^{-1}$ divided into two applications (seeding + sidedressing) at different ratios for maize intercropped with palisadegrass and guineagrass.

\section{MATERIALS AND METHODS}

\section{Site Description and Experimental Design}

A field experiment was carried out during three growing seasons (2004-2005, 2005-2006, 2006-2007) in Botucatu, São Paulo, Brazil ( $48^{\circ} 26^{\prime} \mathrm{W}, 22^{\circ} 51^{\prime} \mathrm{S}, 740 \mathrm{~m}$ above sea level). The climate is Cwa, i.e., tropical with dry winter and warm, rainy summers, according to the Köppen classification. Mean annual precipitation is $1,358 \mathrm{~mm}$ and mean annual temperature is $20.7^{\circ} \mathrm{C}$. Precipitation and temperature during the experiment are shown in Figure 1. The soil type was a clayey, kaolinitic, thermic Typic Haplorthox [United States Department of Agriculture (USDA), 2014] with 630,90 , and $280 \mathrm{~g} \mathrm{~kg}^{-1}$ of clay, silt, and sand, respectively. At the beginning of the experiment, selected chemical properties were determined according to methodology proposed by van Raij et al. (2001) and are shown in Table 1 . The soil $\mathrm{pH}$ was determined in a $0.01 \mathrm{~mol} \mathrm{~L}^{-1} \mathrm{CaCl}_{2}$ suspension $(1: 2: 5$ soil:solution). Soil organic matter was determined by chromic acid digestion (Heanes, 1984). The total acidity at $\mathrm{pH} 7.0(\mathrm{H}+\mathrm{Al})$ was extracted by calcium acetate $\left(0.5 \mathrm{~mol} \mathrm{~L}^{-1}\right.$ at $\left.\mathrm{pH} 7.0\right)$ and evaluated by titration with $0.025 \mathrm{~mol} \mathrm{~L}^{-1} \mathrm{NaOH}$ solution. The available $\mathrm{P}$ and exchangeable basic cations $\left(\mathrm{K}^{+}, \mathrm{Ca}^{2+}\right.$, and $\left.\mathrm{Mg}^{2+}\right)$ 


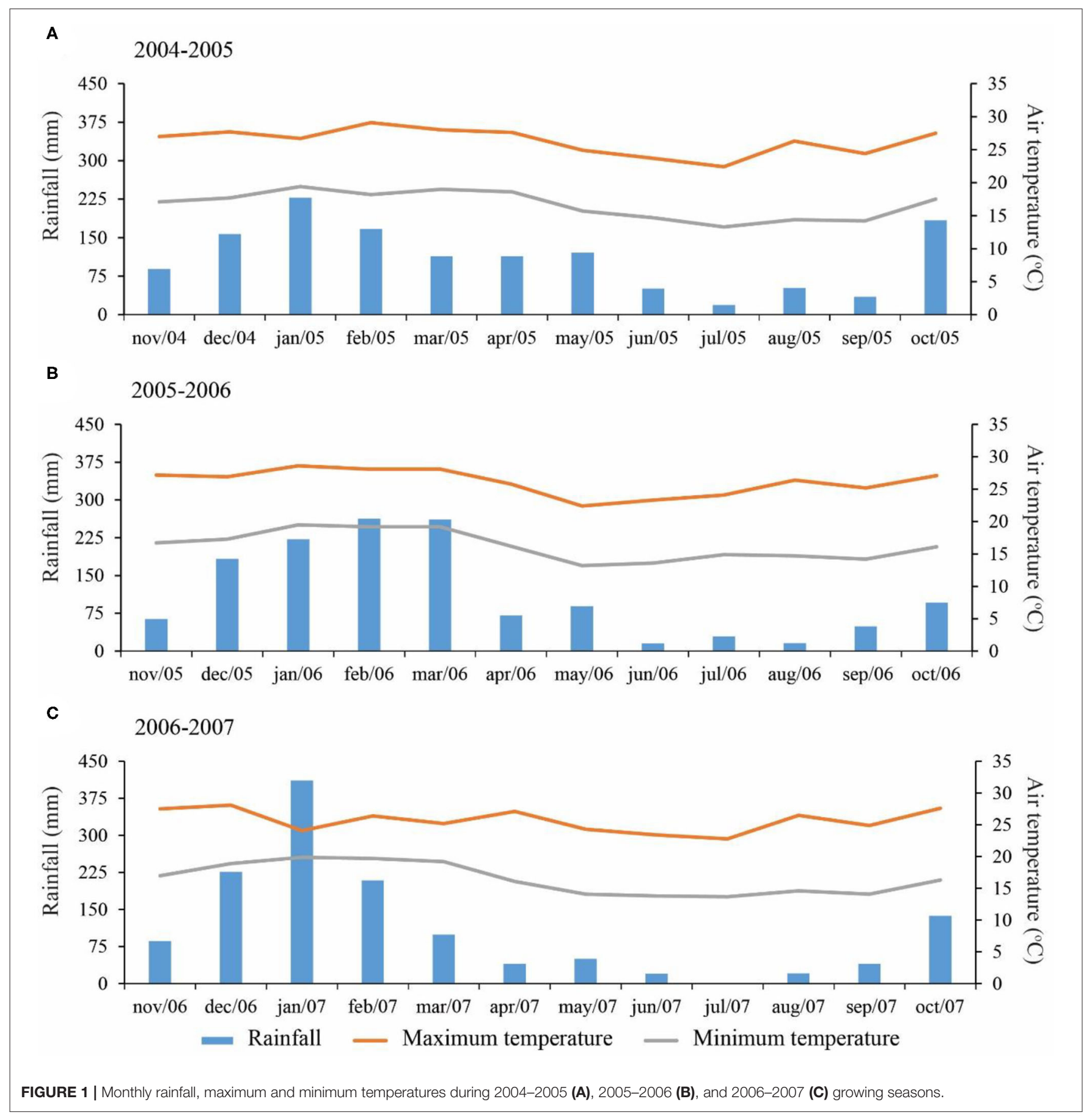

were extracted using an ion resin. The $\mathrm{P}_{\text {resin }}$ concentration was determined colorimetrically (Murphy and Riley, 1962) with a FEMTO 600S spectrophotometer. Exchangeable $\mathrm{K}^{+}, \mathrm{Ca}^{2+}$, and $\mathrm{Mg}^{2+}$ in the extracts were determined by an atomic absorption/flame-emission spectrophotometer (Shimadzu AA6300). The cation exchange capacity (CEC) was obtained by summing the individual cations $(\mathrm{H}, \mathrm{Al}, \mathrm{K}, \mathrm{Ca}$, and $\mathrm{Mg})$. The base saturation (BS) values were calculated using equivalents exchangeable bases and total acidity results (van Raij et al.,
2001). The experimental area had been cropped under NTS since 1999 and the historical crop rotation is presented in Supplementary Table 1.

The experimental design was a randomized complete block with four replicates on different parcels of the same field each year. Treatments consisted of monocropped maize, maize intercropped with palisadegrass [Urochloa brizantha (Hochst. Ex A. Rich) R. Webster "Marandu"], and maize intercropped with guineagrass [Megathyrsus maximus (Jacq.) B. K. Simon and S. 
TABLE 1 | Soil chemical characteristics at two depths in the experimental areas before initiating the experiment $(n=8)$.

\begin{tabular}{|c|c|c|c|c|c|c|c|c|c|c|c|}
\hline $\begin{array}{l}\text { Growing } \\
\text { season }\end{array}$ & Depth & $\begin{array}{c}\mathrm{pH} \\
\left(\mathrm{CaCl}_{2}\right)\end{array}$ & $\begin{array}{c}\operatorname{som}^{t} \\
\left(\mathrm{~g} \mathrm{dm}^{-3}\right)\end{array}$ & $\begin{array}{c}P_{(\text {resin) }} \\
\left(\mathrm{mg} \mathrm{dm}^{-3}\right)\end{array}$ & $\begin{array}{c}\mathrm{H}+\mathrm{Al} \\
\left(\mathrm{mmol}_{\mathrm{c}}\right. \\
\left.\mathrm{dm}^{-3}\right)\end{array}$ & $\begin{array}{c}\mathrm{K}^{+} \\
\left(\mathrm{mmol}_{\mathrm{c}}\right. \\
\left.\mathrm{dm}^{-3}\right)\end{array}$ & $\begin{array}{c}\mathrm{Ca}^{2+} \\
\left(\mathrm{mmol}_{\mathrm{c}}\right. \\
\left.\mathrm{dm}^{-3}\right)\end{array}$ & $\begin{array}{c}\mathrm{SO}_{4}^{2-} \\
\left(\mathrm{mmol}_{\mathrm{c}}\right. \\
\left.\mathrm{dm}^{-3}\right)\end{array}$ & $\begin{array}{c}\mathrm{Mg}^{2+} \\
\left(\mathrm{mmol}_{\mathrm{c}}\right. \\
\left.\mathrm{dm}^{-3}\right)\end{array}$ & $\begin{array}{c}\mathrm{CEC}^{\ddagger} \\
\left(\mathrm{mmol}_{\mathrm{c}}\right. \\
\left.\mathrm{dm}^{-3}\right)\end{array}$ & $\begin{array}{l}B S^{\S} \\
(\%)\end{array}$ \\
\hline \multirow[t]{2}{*}{$2004 / 2005$} & $0.00-0.20 \mathrm{~m}$ & 4.7 & 25 & 14 & 52 & 1.3 & 20 & 4.7 & 10 & 83 & 39 \\
\hline & $0.20-0.40 \mathrm{~m}$ & 4.4 & 22 & 8 & 76 & 0.7 & 15 & 9.8 & 8 & 99 & 24 \\
\hline \multirow[t]{2}{*}{ 2005/2006 } & $0.00-0.20 \mathrm{~m}$ & 4.5 & 24 & 14 & 49 & 1.7 & 19 & 5.1 & 9 & 82 & 39 \\
\hline & $0.20-0.40 \mathrm{~m}$ & 4.3 & 21 & 7 & 73 & 0.7 & 11 & 10.3 & 8 & 92 & 23 \\
\hline \multirow[t]{2}{*}{ 2006/2007 } & $0.00-0.20 \mathrm{~m}$ & 4.8 & 26 & 15 & 47 & 1.6 & 18 & 4.4 & 12 & 78 & 41 \\
\hline & $0.20-0.40 \mathrm{~m}$ & 4.6 & 24 & 9 & 66 & 1.0 & 14 & 9.5 & 9 & 90 & 27 \\
\hline
\end{tabular}

†Soil organic matter.

¥Cation exchange capacity.

$\S$ Base saturation.

W. L. Jacobs "Mombaça"] factorially arranged with N applied at seeding and sidedressing of maize: (i) 0-0 (control), (ii) 1000 , (iii) 70-30, (iv) 50-50, (v) 30-70, and (vi) $0-100 \mathrm{~kg} \mathrm{~N} \mathrm{ha}^{-1}$, respectively (Figures 2A,B). The rate of $100 \mathrm{~kg} \mathrm{~N} \mathrm{ha}^{-1}$ was based on current recommendation and studies in intercropping systems (Cantarella et al., 1997; Mateus et al., 2020). The relatively low rate aimed to reduce environmental impacts from $\mathrm{N}$ loss; however, there is currently no specific recommendation of $\mathrm{N}$ fertilizer application for intercropping systems.

\section{Crop Management}

Soil acidity was ameliorated with dolomite lime application over the soil surface, without soil incorporation. Lime rate was calculated to increase soil base saturation of the surface $0.20 \mathrm{~m}$ of soil to $70 \%$ (Cantarella et al., 1997) and was applied at concentrations of 3.05, 2.95, and $2.66 \mathrm{Mg} \mathrm{ha}^{-1}$ in August 2004, August 2005 and August 2006, respectively. Dolomitic lime consisted of $400 \mathrm{~kg} \mathrm{CaO} \mathrm{ha}^{-1}$ and $120 \mathrm{~kg} \mathrm{MgO} \mathrm{ha}^{-1}$, with $85 \%$ effective calcium carbonate equivalence.

Pearl millet (Pennisetum glaucum) was sown on 2 Oct. 2004, 5 Oct. 2005, and 3 Oct. 2006 at 0.3-m depth using a no-till drill at a seed density of $20 \mathrm{~kg} \mathrm{ha}^{-1}$ to produce crop residues for the ICLS prior to maize in a short-term cultivation. Pearl millet was terminated with glyphosate ( $1.8 \mathrm{~kg} \mathrm{ha}^{-1}$ acid-equivalent), using a spray volume of $250 \mathrm{~L} \mathrm{ha}^{-1} 20$ days before maize sowing. Maize (hybrid 30F90) was sown on 15 Dec. 2004, 18 Dec. 2005 and 20 Dec. 2006 at a depth of $0.3 \mathrm{~m}$ and a density of 60,000 seeds ha ${ }^{-1}$ using a no-till drill. Each plot consisted of ten 20-m-long rows of maize and row spacing of $0.45 \mathrm{~m}$. Sampling area was considered within a buffer zone of $0.45 \mathrm{~m}$ from the perimeter of each plot.

Baseline fertilization of maize in the sowing furrows consisted of $84 \mathrm{~kg} \mathrm{ha}^{-1} \mathrm{P}_{2} \mathrm{O}_{5}$ as triple superphosphate and $48 \mathrm{~kg} \mathrm{ha}^{-1}$ $\mathrm{K}_{2} \mathrm{O}$ as potassium chloride in a $08-28-16$ NPK formula for all treatments. At seeding, $\mathrm{N}$ application treatments were applied as urea and distributed between 0.5 and $0.10 \mathrm{~m}$ next to the seed row by superficial broadcasting. For treatments with intercropping, palisadegrass and guineagrass were simultaneously sown with maize at densities of 15.3 and $15.9 \mathrm{~kg} \mathrm{ha}^{-1}$ seed (34\% viable seeds), respectively. Palisadegrass and guineagrass were mixed with fertilizer and sown at depths of 0.08 and $0.06 \mathrm{~m}$ below soil surface, respectively. Monocropped maize was sown at the same time using the same practices. In addition, monocropped palisade grass and guinea grass were seeded at the same time as the forages in intercropping systems using the same practices. The monocropped forages plots were the same size and were only used to calculate the intercropping competition factors.

Maize seedlings emerged 5 days after sowing (20 Dec. 2004, 23 Dec. 2005 and 25 Dec. 2006) and forage seedlings emerged 15 days after sowing, on average, for each growing season. Maize and forage were cultivated according to crop needs; atrazine [6-chloro- $\mathrm{N}^{2}$-ethyl- $\mathrm{N}^{4}$-isopropyl-1,3,5-triazine-2,4-diamine] (1.0 kg ha $\mathrm{ha}^{-1}$ acid-equivalent) using a spray volume of $200 \mathrm{~L}$ $\mathrm{ha}^{-1}$ was applied to control emergence of annual broadleaf weeds, deltamethrin [(S)-cyano-(3-phenoxyphenyl)-methyl] (1R,3R)-3-(2,2-dibromoethenyl)-2,2-dimethyl-cyclopropane-

1-carboxylate $\left(5 \mathrm{~g} \mathrm{ha}^{-1}\right.$ active ingredient) was used against fall armyworm (Spodoptera frugiperda). Sidedress $\mathrm{N}$ fertilization was applied according to the treatments at $\mathrm{V}_{5}$ maize growth stage (five expanded leaves). Physiological maturity averaged 128, 132, and 130 days after emergence in the 2004-2005, 2005-2006, and 2006-2007, respectively. Maize harvest was 7 days after physiological maturity using a mechanical harvester. Maize, palisadegrass and guineagrass were harvested separately from eight central rows.

\section{Sampling and Analyses}

When $50 \%$ of maize plants were in full flowering stage, 20 random leaf samples per plot were collected from the fourth leaf with visible sheath from the apex for nutrition diagnoses (Cantarella et al., 1997). Leaves were washed, dried in forced air circulation at $65^{\circ} \mathrm{C}$ for $72 \mathrm{~h}$, ground, and $\mathrm{N}, \mathrm{P}, \mathrm{K}, \mathrm{Ca}, \mathrm{Mg}$, and $\mathrm{S}$ concentrations in leaves were determined according to Malavolta et al. (1997). The samples were digested with sulfuric acid for $\mathrm{N}$ determination and with a nitro-perchloric solution for the other nutrients. The leaf $\mathrm{N}, \mathrm{P}, \mathrm{S}$ concentrations were determined by semi-micro-Kjeldahl distillation, colorimetry, and turbidmetry methods, respectively. The leaf $\mathrm{K}, \mathrm{Ca}$, and $\mathrm{Mg}$ concentrations were determined by atomic absorption spectrophotometry.

Kernel weight was determined and transformed to maize yield $\mathrm{ha}^{-1}$ by correcting to $13 \%$ grain moisture. Plant population was determined by counting the number of plants in the four central 5-m rows per plot at harvest. Number of ears per plant, number of 
A Integrated crop-livestock systems

\section{Cropping systems}
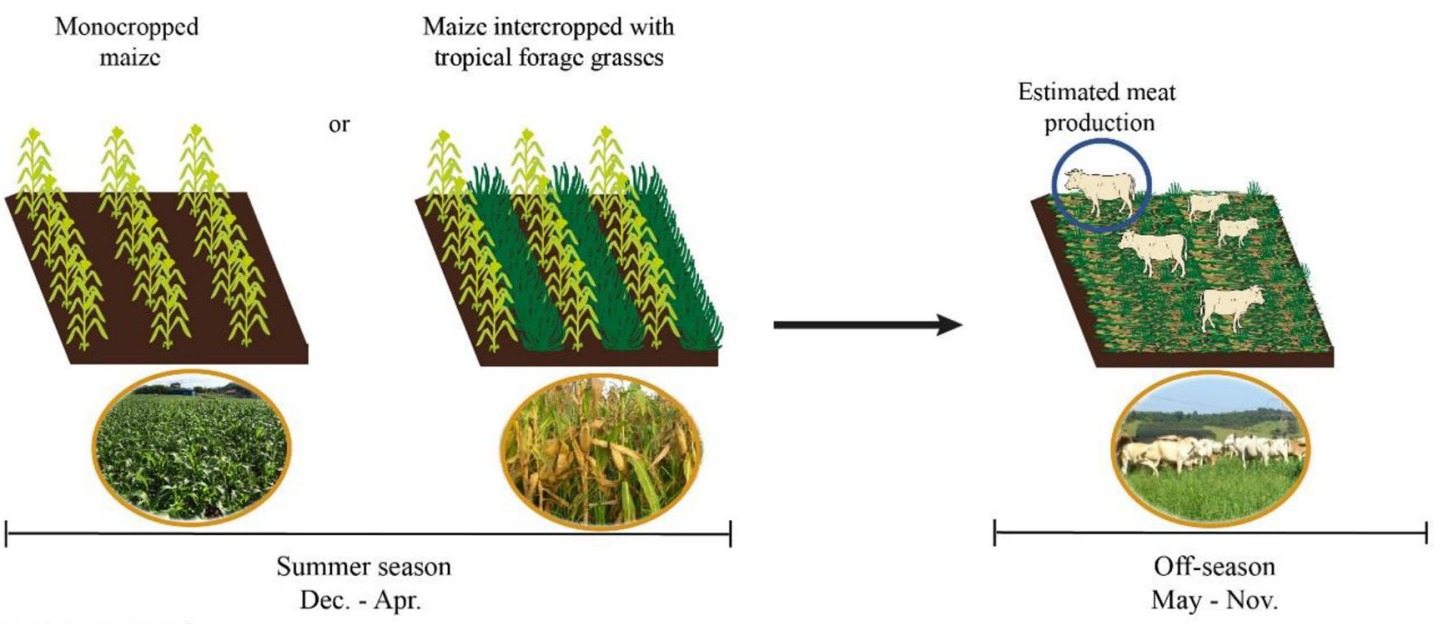

B Nitrogen management
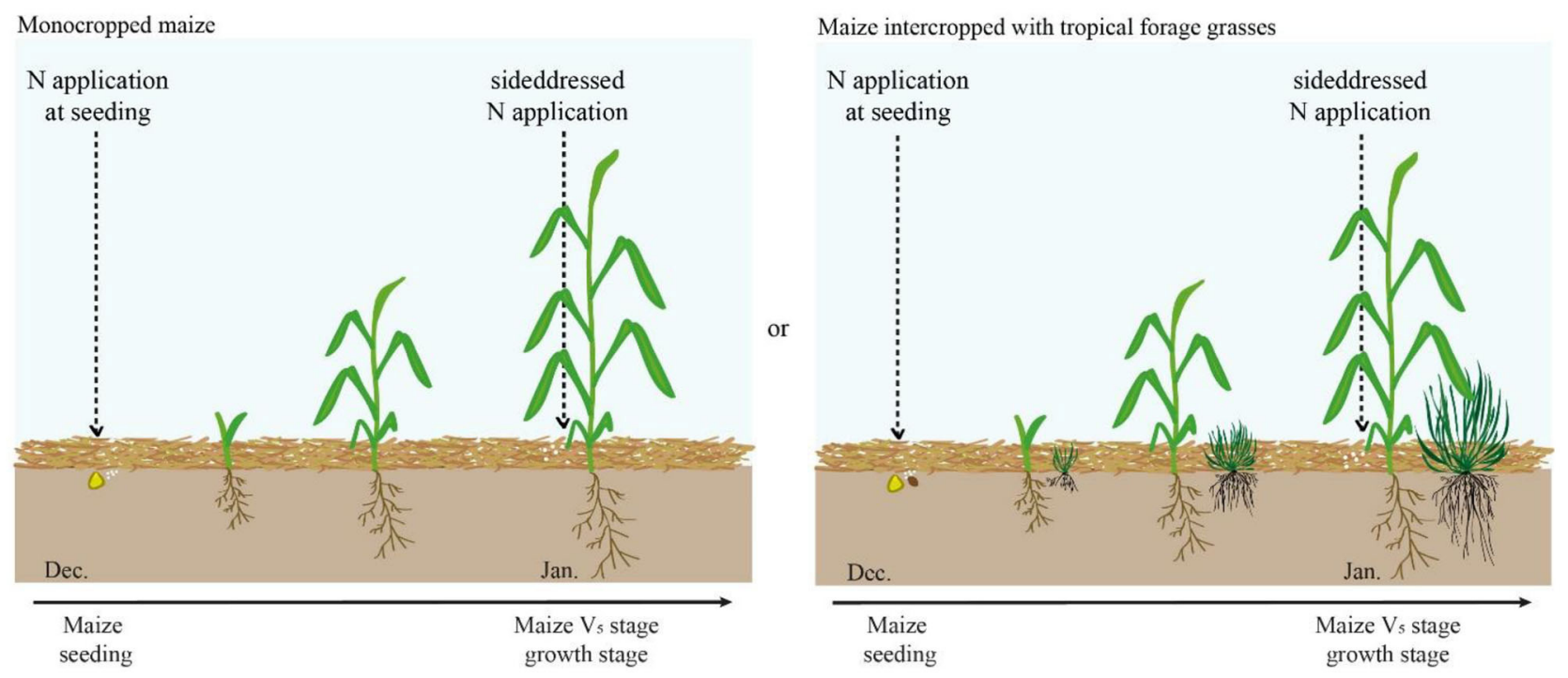

FIGURE 2 | (A) Scheme of cropping systems arrange in the summer season. Grazing by animals was not performed after maize harvest in off season and meat production was estimated using Large Ruminant Nutrition System model. (B) Timing of $\mathrm{N}$ application (seeding + sidedressing) in the monocrop and intercrop system in the summer season.

kernels per ear, and 100-kernel weight were determined at harvest and evaluated from 10 plants per plot chosen at random.

From the time of maize harvest, forage dry matter of palisadegrass and guineagrass were evaluated at 55 days (first cut) and 145 days (second cut), in June and September, respectively. Forages were cut at $0.25 \mathrm{~m}$ from the soil surface $\left(2 \mathrm{~m}^{2}\right.$ area each area and row spacing $=0.45 \mathrm{~m}$ ) and removed from the plots. The remainder of plots were cut using a manual mechanical rotary mower to provide faster forage regrowth. Forage dry matter was dried by forced-air circulation at $65^{\circ} \mathrm{C}$ for $72 \mathrm{~h}$ until constant weight, and weighed. Data were extrapolated to $\mathrm{Mg} \mathrm{ha}^{-1}$. A sub-sample of forage dry matter was used to determine total $\mathrm{N}$ concentration for crude protein (CP). CP was calculated by formula: $\mathrm{CP}(\%)=\operatorname{total} \mathrm{N}(\%) \times 6.25$ (Horwitz, 1980).

\section{Intercropping Competition Factors}

To study the competition effects between crops and to evaluate intercrop performance, different competition functions were calculated: land equivalent ratio (LER), relative crowding $(K)$, and aggressivity index $(A)$. The LER was used to evaluate the land use advantage provided by intercropping (Mead and Willey, 1980):

$$
\mathrm{LER}=\mathrm{Y} 1,2 / \mathrm{Y} 1,1+\mathrm{Y} 2,1 / \mathrm{Y} 2,2
$$

where $\mathrm{Y}$ is the aboveground biomass of crops, and suffixes 1 and 2 denote the crops: (1) maize and (2) palisadegrass or guineagrass. Therefore, $\mathrm{Y}_{1,2}$ is the aboveground biomass of maize when grown in a mixture with grasses, $\mathrm{Y}_{1,1}$ is the yield of maize 
when grown in a monoculture, $\mathrm{Y}_{2,1}$ is the aboveground biomass of the forage (palisadegrass or guineagrass) when grown in a mixture with maize, and $\mathrm{Y}_{2,2}$ is the aboveground biomass of the forage (palisadegrass or guineagrass produced 839 and $1,327 \mathrm{Mg}$ $\mathrm{ha}^{-1}$, respectively) when grown in a monoculture.

Relative crowding coefficient ( $K$ values) is a measure of plant competition theory as an index of the relative competitive abilities between plants in an intercropping system to evaluate and compare the competitive ability of one species to another in a mixture (Zhang et al., 2011). $K$ was calculated according the method of Agegnehu et al. (2006) as follows:

$$
\begin{array}{r}
(\mathrm{K}) \text { maize }=\mathrm{Y} 1,2 \times \mathrm{Z} 2,1 /(\mathrm{Y} 1,1-\mathrm{Y} 1,2) \times \mathrm{Z} 1,2 \text { or } \\
(\mathrm{K}) \text { forage }=\mathrm{Y} 2,1 \times \mathrm{Z} 1,2 /(\mathrm{Y} 2,2-\mathrm{Y} 2,1) \times \mathrm{Z} 2,1
\end{array}
$$

where $Y$ and suffixes 1 and 2 denote as described for LER, $Z_{1,2}$ is the sown proportion of maize, and $Z_{2,1}$ is the sown proportion of the forage species. For this calculation, the plant density of each species was evaluated on the day of maize harvest. Greater $K$ value of one species indicates it is more competitive and dominant than another species in the intercropping system ( $\mathrm{Li}$ et al., 1999; Wahla et al., 2009).

Aggressivity index $(A)$ was calculated to determine relative yield of crop 1 with crop 2 in intercropping (Takim, 2012):

$$
\begin{aligned}
& (\mathrm{A}) \text { maize }=(\mathrm{Y} 1,2 / \mathrm{Y} 1,1 \mathrm{Y} 1,2)-(\mathrm{Y} 2,1 / \mathrm{Y} 2,2 \mathrm{Y} 2,1) \text { or } \\
& (\mathrm{A}) \text { forage }=(\mathrm{Y} 2,1 / \mathrm{Y} 2,2 \mathrm{Y} 2,1)-(\mathrm{Y} 1,2 / \mathrm{Y} 1,1 \mathrm{Y} 1,2)
\end{aligned}
$$

where $\mathrm{Y}$ and the suffixes 1 and 2 denote the same as used in LER and $(\mathrm{K})$. If $(\mathrm{A})_{\text {maize }}=0$, crops were equally competitive, if $(A)_{\text {forage }}$ was negative, then maize dominated, if $(A)_{\text {forage }}$ was positive, then forage dominated.

\section{Economic Valuation and Estimated Meat Production}

Production costs per hectare of monocropped maize and maize intercropped with forages were estimated (CONAB, 2018). Differences in input costs were forage seed and $\mathrm{N}$ fertilizer, as sowing maize monocrop and intercropped forage seeds were the same process. Maize grain yield $\left(\mathrm{kg} \mathrm{ha}^{-1}\right)$ was calculated and multiplied by the value per $\mathrm{kg}$.

Although grazing by animals was not carried out for the palisadegrass and guineagrass after maize grain harvest, meat production was calculated using Large Ruminant Nutrition System (LRNS; http://nutritionmodels.tamu.edu/lrns.html) model to estimate grazing performance by animals on tropical perennial grasses. The LRNS model is based on the Net Carbohydrate and Protein System (CNCPS), version 5 (Fox et al., 2004). Energy and protein requirements, performance and dry matter intake by each individual cattle fed in a group were predicted for continuously grazed $450 \mathrm{~kg}$ Nellore bulls with 52\% carcass yield and 22\% Body Fat Grading System. Performance values were predicted from the nutritional composition of palisadegrass and guineagrass and $\mathrm{N}$ fertilizer applied.

Dry matter intake by each individual cattle fed in a group was $9.9-10.0 \mathrm{~kg}$ of dry matter day ${ }^{-1}$. Average daily gain (ADG) was used to estimate meat production based on the allowable metabolizable energy and protein gain, since $\mathrm{CP}$ of forage was $9.3-14.6 \%$. A animal grazing time was calculated using a method similar to Crusciol et al. (2012), in which a $55 \mathrm{~d}$ forage accumulation period occurred after maize harvest followed by two 60 -day grazing periods with a 30 -day rest period in between grazing periods. Stocking rate was estimated from forage dry matter production, time of animal grazing (days per cut), dry matter intake, and grazing efficiency. Total cattle meat produced per hectare was calculated from stocking rate multiplied by the components of ADG, time of animal grazing, and carcass yield (52\%).

Gross revenue $\mathrm{ha}^{-1}$ was calculated by the formula: (price per $\mathrm{kg} \times$ maize yield) + (price per $\mathrm{kg} \times$ estimated meat production). Net return per ha was calculated by the formula: (gross revenue - cost ha ${ }^{-1}$ ). The Brazilian national average price used was from the last 5 years and values were converted to US\$ (Agrolink, 2018).

\section{Statistical Analyses}

All data were initially tested for normality using the ShapiroWilk test from the UNIVARIATE procedure using the statistical software R (version 3.5.2) with the package "agricolae" (Mendiburu, 2015). All data were distributed normally (W $\geq 0.90$ ). Cropping systems, $\mathrm{N}$ management treatments, and their interactions were considered fixed effects. Growing season and its interaction with cropping systems and $\mathrm{N}$ managements were not significant at $P<0.05$ for any of the dependent variables. Thus, data were combined across growing seasons. Block was considered a random variable. Analysis of variance (ANOVA) was performed and if the null hypothesis was rejected, means were compared using LSD teste $(P \leq 0.05)$.

\section{RESULTS}

\section{Plant Nutrition, Agronomic Characteristics, Kernels and Production Attributes of Maize}

Monocropped maize and maize intercropped with palisadegrass had greater leaf $\mathrm{N}$ concentrations than maize intercropped with guineagrass (Supplementary Table 2). Maize intercropped with palisadegrass had greater leaf $\mathrm{P}, \mathrm{K}$, and $\mathrm{S}$ concentrations than monocropped maize and maize intercropped with guineagrass. Although the interaction of intercropping system and $\mathrm{N}$ management was not statistically significant for nutrient concentration, all intercropping systems that received $\mathrm{N}$ application had greater leaf N, P, and S concentrations than the control without $\mathrm{N}$ fertilizer (Supplementary Table 2).

Intercropping system did not influence plant population, ears per plant, kernels per ear, and 100-kernel weight (Table 2). However, monocropped maize had greater shoot dry matter and grain yield compared with intercropping systems of maize with palisadegrass and guineagrass. Time of $\mathrm{N}$ application did not influence plant population, but all treatments with some $\mathrm{N}$ application led to greater number of ears per plant, number of kernels per ear, 100-kernel weight, shoot dry matter, and grain yield of maize compared to the control without $\mathrm{N}$ application (Table 2). Shoot dry matter and grain yield of maize were greater in all $\mathrm{N}$ management systems with some $\mathrm{N}$ applied at seeding 
TABLE 2 | Agronomic characteristics (plant population and number of ears per plant), kernels attributes (number of kernels per ear and 100-kernel weight) and production attributes (shoot dry matter and grain yield) of maize as affected by intercropping system, $\mathrm{N}$ management in the three growing seasons.

\begin{tabular}{|c|c|c|c|c|c|c|}
\hline \multirow[b]{2}{*}{ Treatment } & \multicolumn{2}{|c|}{ Agronomic characteristics } & \multicolumn{2}{|c|}{ Kernel attributes } & \multicolumn{2}{|c|}{ Production attributes } \\
\hline & Plant population & Ears per plant & Kernels per ear & 100-kernel weight & Shoot dry matter & Grain Yield \\
\hline & Thousand plants ha $\mathrm{h}^{-1}$ & no. & no. & g & $\mathrm{Mg} \mathrm{ha}^{-1}$ & $\mathrm{Mg} \mathrm{ha}^{-1}$ \\
\hline \multicolumn{7}{|c|}{ Intercropping system (IC) } \\
\hline Monocropped maize & $60.1 \mathrm{a}^{\S}$ & $1.13 a$ & $403 a$ & $32 a$ & $17.6 \mathrm{a}$ & $8.7 \mathrm{a}$ \\
\hline Maize + palisadegrass & $59.7 \mathrm{a}$ & $1.14 \mathrm{a}$ & $380 a$ & $32 \mathrm{a}$ & $16.0 \mathrm{~b}$ & $8.2 \mathrm{~b}$ \\
\hline Maize + guineagrass & $59.9 a$ & $1.13 \mathrm{a}$ & $370 a$ & $31 \mathrm{a}$ & $15.1 \mathrm{~b}$ & $7.9 \mathrm{~b}$ \\
\hline \multicolumn{7}{|l|}{$\mathbf{N}$ management $(\mathbf{N M})^{\ddagger}$} \\
\hline $0-0$ & $59.2 \mathrm{a}$ & $0.89 c$ & $333 b$ & $29 b$ & $9.6 \mathrm{c}$ & $4.9 \mathrm{c}$ \\
\hline $100-0$ & $60.0 \mathrm{a}$ & $1.22 \mathrm{a}$ & $381 a$ & $33 a$ & $17.7 \mathrm{a}$ & $9.1 \mathrm{a}$ \\
\hline $70-30$ & $60.5 \mathrm{a}$ & $1.19 a$ & $399 a$ & $32 \mathrm{a}$ & $18.2 \mathrm{a}$ & $9.3 \mathrm{a}$ \\
\hline $50-50$ & $59.7 \mathrm{a}$ & $1.20 \mathrm{a}$ & $404 a$ & $33 \mathrm{a}$ & $18.4 \mathrm{a}$ & $9.4 \mathrm{a}$ \\
\hline $30-70$ & $60.2 \mathrm{a}$ & $1.20 \mathrm{a}$ & $396 a$ & $32 a$ & $17.7 \mathrm{a}$ & $9.1 \mathrm{a}$ \\
\hline $0-100$ & $59.7 \mathrm{a}$ & $1.10 \mathrm{~b}$ & $391 \mathrm{a}$ & $32 \mathrm{a}$ & $15.7 \mathrm{~b}$ & $8.0 \mathrm{~b}$ \\
\hline \multicolumn{7}{|l|}{ F probability } \\
\hline IC & 0.313 & 0.109 & 0.074 & 0.563 & $<0.001$ & $<0.001$ \\
\hline NM & 0.549 & $<0.001$ & $<0.001$ & $<0.001$ & $<0.001$ & $<0.001$ \\
\hline $\mathrm{IC} \times \mathrm{NM}$ & 1.000 & 0.083 & 0.656 & 0.724 & 0.532 & 0.963 \\
\hline
\end{tabular}

$\S$ Values followed by the same letter are not significantly different at $P \leq 0.05$ (LSD test).

${ }^{\ddagger} A$ rate of $100 \mathrm{~kg} \mathrm{~N} \mathrm{ha-1}$ applied in two-split management at maize seeding and $V_{5}$ growth stage sidedressing.

(i.e., $100-0,70-30,50-50$, and $30-70 \mathrm{~kg} \mathrm{~N}^{-1}$ ) than with no $\mathrm{N}$ applied at seeding (i.e., $0-0$ and $0-100 \mathrm{~kg} \mathrm{~N} \mathrm{ha}^{-1}$ ).

\section{Forage Characteristics and Estimated Meat Production}

Forage dry matter production, estimated animal stocking rate and estimated meat production were influenced by intercropping system in the second cut but not in the first cut (Table 3). Forage dry matter production in the second cut was $23 \%$ greater when maize was intercropped with palisadegrass than with guineagrass, although CP in the second cut was similar in the two intercropping systems. For both intercropping systems, forage dry matter production, $\mathrm{CP}$, estimated animal stocking rate, and estimated meat production were greater when $\mathrm{N}$ fertilizer was applied than in the control $\left(0-0 \mathrm{~kg} \mathrm{~N} \mathrm{ha-}{ }^{1}\right)$ in the first and second cuts.

\section{Land Equivalent Ratio and Intercropping Competition Factors}

All LER values of maize and forages were lower under intercropping compared with the respective monoculture (Table 4). When combined, LER of maize intercropped with palisadegrass (1.06 average) was more productive than each component separately when receiving $\mathrm{N}$, independent of the split- $\mathrm{N}$ ratio. In contrast, LER of maize intercropped with guineagrass (0.95 average) was less productive than individual components grown separately for all $\mathrm{N}$ application conditions.

The intercropping competition factor $(K)$ values shown in Table 4 are the interspecific competitive abilities. Compared with the unfertilized control, $K_{\text {maize }}$ and $K_{\text {forage }}$ were greater for maize intercropped with both palisadegrass and guineagrass. The aggressivity index $(A)$ showed that maize was less competitive than palisadegrass and guineagrass in all treatments. Maize was more competitive with guineagrass without $\mathrm{N}$ fertilizer application.

\section{Revenue}

Not supplying $\mathrm{N}$ fertilizer to cropping systems resulted in the lowest estimated net profit (Table 5). When supplying $100 \mathrm{~kg}$ $\mathrm{N} \mathrm{ha}{ }^{-1}$, net profit was similar among the different split $\mathrm{N}$ applications, except when no $\mathrm{N}$ fertilizer was applied at seeding $\left(0-100 \mathrm{~kg} \mathrm{~N} \mathrm{ha}^{-1}\right)$, which had lower net profit compared to other treatments with $\mathrm{N}$ application. Intercropping maize with either forage grass had greater net profit compared to monocropped maize when supplied with $\mathrm{N}$, because of significant meat production during the winter/spring.

\section{DISCUSSION}

\section{Maize and Tropical Forage Grass Responses}

Our study provides a novel alternative identifying potential agricultural systems to improve food production by intercropping maize with forage grasses and selecting the proper $\mathrm{N}$ management. Currently, recommendations for $\mathrm{N}$ fertilizer application consider only monocropping (maize or forage grass) in the summer/fall or fodder in the winter/spring for grain production (Cantarella et al., 1997). Our study shows that split $\mathrm{N}$ application timing can increase responses of both maize and forage grasses, while meeting grain crop requirements and high 
TABLE 3 | Forage dry matter (DM) production and crude protein (CP) concentration, estimated animal stocking rate, and estimated meat production as affected by intercropping systems and $\mathrm{N}$ management in three growing seasons and ANOVA significance.

\begin{tabular}{|c|c|c|c|c|c|c|c|c|}
\hline \multirow[t]{2}{*}{ Treatment } & \multicolumn{2}{|c|}{ Forage DM (Mg ha-1) } & \multicolumn{2}{|c|}{ Crude protein (\%) } & \multicolumn{2}{|c|}{ Stocking rate $\left(\mathrm{AU} \mathrm{ha} \mathrm{h}^{-1}\right)^{\mathbb{I}}$} & \multicolumn{2}{|c|}{ Meat production $\left(\mathrm{kg} \mathrm{ha}^{-1}\right)^{y}$} \\
\hline & First cut ${ }^{t}$ & Second cut ${ }^{\dagger}$ & First cut & Second cut & First cut & Second cut & First cut & Second cut \\
\hline \multicolumn{9}{|c|}{ Intercropping system (IC) } \\
\hline Maize + palisadegrass & $2.2 a^{\S}$ & $5.8 \mathrm{a}$ & $12.5 \mathrm{a}$ & $12.8 \mathrm{a}$ & $2.2 \mathrm{a}$ & $5.8 \mathrm{a}$ & $53.1 \mathrm{a}$ & $140.5 \mathrm{a}$ \\
\hline Maize + guineagrass & $2.1 \mathrm{a}$ & $4.7 \mathrm{~b}$ & $12.6 \mathrm{a}$ & $13.4 \mathrm{a}$ & $2.1 \mathrm{a}$ & $4.7 \mathrm{~b}$ & $49.5 \mathrm{a}$ & $118.4 b$ \\
\hline \multicolumn{9}{|l|}{$\mathbf{N}$ management $(\mathrm{NM})^{\ddagger}$} \\
\hline $0-0$ & $1.4 \mathrm{~b}$ & $3.1 \mathrm{~b}$ & $11.2 \mathrm{~b}$ & $10.1 \mathrm{~b}$ & $1.4 \mathrm{~b}$ & $5.7 \mathrm{a}$ & $30.0 \mathrm{~b}$ & $59.0 \mathrm{~b}$ \\
\hline $100-0$ & $2.3 \mathrm{a}$ & $5.7 \mathrm{a}$ & $12.8 \mathrm{a}$ & $13.8 \mathrm{a}$ & $2.3 \mathrm{a}$ & $5.8 \mathrm{a}$ & $55.7 \mathrm{a}$ & $145.2 \mathrm{a}$ \\
\hline 70-30 & $2.4 \mathrm{a}$ & $5.8 a$ & $12.9 \mathrm{a}$ & $13.9 a$ & $2.4 \mathrm{a}$ & $5.7 \mathrm{a}$ & $57.0 \mathrm{a}$ & $147.6 \mathrm{a}$ \\
\hline $50-50$ & $2.3 a$ & $5.7 \mathrm{a}$ & $12.5 \mathrm{a}$ & $13.7 \mathrm{a}$ & $2.3 a$ & $5.7 \mathrm{a}$ & $54.5 \mathrm{a}$ & $140.0 \mathrm{a}$ \\
\hline $30-70$ & $2.3 a$ & $5.7 \mathrm{a}$ & $12.8 \mathrm{a}$ & $13.8 \mathrm{a}$ & $2.3 a$ & $5.6 a$ & $56.3 a$ & $144.5 \mathrm{a}$ \\
\hline $0-100$ & $2.3 \mathrm{a}$ & $5.6 \mathrm{a}$ & $12.7 \mathrm{a}$ & $13.7 \mathrm{a}$ & $2.3 \mathrm{a}$ & $5.7 \mathrm{a}$ & $54.3 \mathrm{a}$ & $140.5 \mathrm{a}$ \\
\hline \multicolumn{9}{|l|}{ F probability } \\
\hline IC & 0.148 & $<0.001$ & 0.127 & 0.081 & 0.198 & $<0.001$ & 0.102 & $<0.001$ \\
\hline NM & $<0.001$ & $<0.001$ & $<0.001$ & $<0.001$ & $<0.001$ & $<0.001$ & $<0.001$ & $<0.001$ \\
\hline $\mathrm{IC} \times \mathrm{NM}$ & 0.263 & 0.222 & 0.387 & 0.155 & 0.265 & 0.175 & 0.168 & 0.365 \\
\hline
\end{tabular}

${ }^{\dagger}$ First and second cut in June and September, respectively.

$\S$ Values followed by the same letter are not significantly different at $P \leq 0.05$ (LSD test).

${ }^{\ddagger} A$ rate of $100 \mathrm{~kg} \mathrm{~N} \mathrm{ha}^{-1}$ applied in two-split management at maize seeding and $V_{5}$ growth stage sidedressing.

I1 $1 \mathrm{AU}$ (animal unit) $=450 \mathrm{~kg}$ of body weight.

${ }^{\Psi}$ Estimated meat production $=\mathrm{kg}$ of body weight gain (cattle) per ha (estimated) $\times 52 \%$ of carcass yield.

TABLE 4 | Land equivalent ratio (LER), relative crowding coefficient (K), and aggressivity $(A)$ of maize, palisadegrass, and guineagrass intercropped as a function of $\mathrm{N}$ fertilizer applied for maize crop.

\begin{tabular}{|c|c|c|c|c|c|c|c|}
\hline \multirow[t]{2}{*}{ Treatment } & \multicolumn{3}{|c|}{ LER } & \multicolumn{2}{|c|}{$K$} & \multicolumn{2}{|c|}{$A$} \\
\hline & Maize $^{t}$ & Forage $^{\ddagger}$ & Total $^{\ddagger}$ & Maize & Forage & Maize & Forage \\
\hline \multicolumn{8}{|c|}{ Maize \pm palisadegrass } \\
\hline $0-0^{\Psi}$ & $0.86^{\S}$ & 0.09 & 0.95 & 4.00 & 0.15 & -0.0002994 & 0.0002994 \\
\hline $100-0$ & 0.91 & 0.16 & 1.06 & 6.93 & 0.27 & -0.0007091 & 0.0007091 \\
\hline 70-30 & 0.91 & 0.16 & 1.07 & 7.27 & 0.27 & -0.0007196 & 0.0007196 \\
\hline $50-50$ & 0.91 & 0.15 & 1.06 & 7.30 & 0.26 & -0.0007247 & 0.0007247 \\
\hline $30-70$ & 0.91 & 0.16 & 1.07 & 7.34 & 0.26 & -0.0007070 & 0.0007070 \\
\hline $100-0$ & 0.91 & 0.14 & 1.05 & 7.24 & 0.24 & -0.0006394 & 0.0006394 \\
\hline \multicolumn{8}{|c|}{ Maize \pm guineagrass } \\
\hline $0 \mathrm{~kg} \mathrm{~N} \mathrm{ha}^{-1}$ & 0.82 & 0.06 & 0.88 & 3.19 & 0.09 & -0.0001518 & 0.0001518 \\
\hline $100-0$ & 0.86 & 0.09 & 0.95 & 4.13 & 0.15 & -0.0002579 & 0.0002579 \\
\hline $70-30$ & 0.86 & 0.09 & 0.95 & 4.39 & 0.14 & -0.0002684 & 0.0002684 \\
\hline $50-50$ & 0.86 & 0.09 & 0.95 & 4.51 & 0.14 & -0.0002735 & 0.0002735 \\
\hline $30-70$ & 0.86 & 0.09 & 0.95 & 4.24 & 0.15 & -0.0002558 & 0.0002558 \\
\hline $100-0$ & 0.86 & 0.10 & 0.96 & 4.23 & 0.15 & -0.0001883 & 0.0001883 \\
\hline
\end{tabular}

${ }^{\Psi}$ First value means the $\mathrm{kg} \mathrm{N} \mathrm{ha-1}$ applied at seeding and the second value means the $\mathrm{kg} \mathrm{ha}^{-1}$ applied sidedressing at maize $V_{6}$ growth.

${ }^{\dagger}$ Relative to respective monoculture.

${ }^{\ddagger}$ Relative to respective intercropping system.

$\S$ Value above 1 means positive impact.

$\mathrm{N}$ demand of both crops. Furthermore, this research provides as a novel outcome that intercropping systems combined with fertilizer $\mathrm{N}$ management showed effectiveness in improving the overall productivity of the whole system, especially for enhancing meat production and revenue for farmers.
Competition between forage and maize may have been reduced in this study due to the relatively long growing season with the 130-day maturity maize hybrid (Crusciol et al., 2013). Sowing plants with earlier relative maturity may benefit an intercropping system and decrease the competition between 


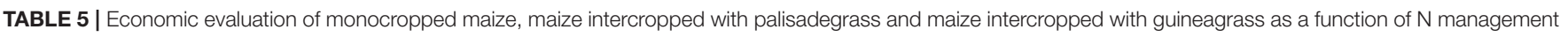
for maize (average of three growing seasons).

\begin{tabular}{|c|c|c|c|c|c|c|c|}
\hline Treatment & $\operatorname{Cost}^{\Omega}$ & CY $¥$ & $\begin{array}{c}\text { Total } \\
\text { maize }^{\S}\end{array}$ & $\begin{array}{c}\text { Meat } \\
\text { production }^{\alpha}\end{array}$ & $\begin{array}{c}\text { Total } \\
\text { meat }\end{array}$ & Gross $^{\dagger}$ & Net $^{\ddagger}$ \\
\hline & US\$ ha-1 & $\mathrm{Mg} \mathrm{ha}^{-1}$ & US\$ ha ${ }^{-1}$ & $\mathrm{~kg} \mathrm{ha}^{-1}$ & US\$ ha-1 & US\$ ha-1 & US\$ ha $\mathbf{h}^{-1}$ \\
\hline \multicolumn{8}{|c|}{ Monocropped maize } \\
\hline $0-0$ & 604 & 5.3 & 1,081 & 0 & 0 & 1,081 & 477 \\
\hline $100-0$ & 643 & 9.5 & 1,937 & 0 & 0 & 1,937 & 1,294 \\
\hline $70-30$ & 643 & 9.7 & 1,978 & 0 & 0 & 1,978 & 1,335 \\
\hline $50-50$ & 643 & 9.8 & 1,998 & 0 & 0 & 1,998 & 1,355 \\
\hline $30-70$ & 643 & 9.5 & 1,937 & 0 & 0 & 1,937 & 1,294 \\
\hline $0-100$ & 643 & 8.4 & 1,713 & 0 & 0 & 1,713 & 1,070 \\
\hline \multicolumn{8}{|c|}{ Maize \pm palisadegrass } \\
\hline $0-0$ & 626 & 4.7 & 958 & 91 & 272 & 1,230 & 604 \\
\hline $100-0$ & 666 & 9.1 & 1,856 & 214 & 643 & 2,499 & 1,833 \\
\hline 70-30 & 666 & 9.3 & 1,896 & 221 & 664 & 2,560 & 1,894 \\
\hline 50-50 & 666 & 9.4 & 1,917 & 206 & 618 & 2,535 & 1,869 \\
\hline $30-70$ & 666 & 9.1 & 1,856 & 218 & 654 & 2,510 & 1,844 \\
\hline $0-100$ & 666 & 8.0 & 1,631 & 211 & 634 & 2,265 & 1,599 \\
\hline \multicolumn{8}{|c|}{ Maize \pm guineagrass } \\
\hline $0-0$ & 628 & 4.7 & 958 & 87 & 262 & 1,220 & 592 \\
\hline $100-0$ & 667 & 8.7 & 1,774 & 187 & 562 & 2,336 & 1,669 \\
\hline 70-30 & 667 & 8.9 & 1,815 & 188 & 563 & 2,378 & 1,711 \\
\hline 50-50 & 667 & 9.0 & 1,835 & 183 & 548 & 2,383 & 1,716 \\
\hline $30-70$ & 667 & 8.7 & 1,774 & 184 & 551 & 2,325 & 1,658 \\
\hline 0-100 & 667 & 7.7 & 1,570 & 178 & 534 & 2,104 & 1,437 \\
\hline
\end{tabular}

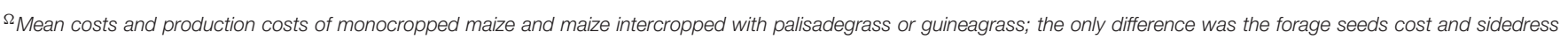
nitrogen used for the maize crop.

$¥ \mathrm{CY}$ is the maize yield.

$\S$ Total $=k g$ of maize ha ${ }^{-1} \times$ US\$ 0.20

${ }^{\alpha}$ Meat production $=\mathrm{kg}$ of body weight gain (cattle) ha ${ }^{-1}$ (estimate) $\times 52 \%$ of carcass yield (sum of EMP First and Second cuts).

ITotal meat $=$ meat production $\times$ US\$3.00.

† Gross is the revenue per ha, which was calculated using the formula: total maize + total meat.

${ }^{\ddagger}$ Net is the return per ha, which was calculated using the formula (gross $h a^{-1}$-cost ha ${ }^{-1}$ ).

species (Pariz et al., 2009; Crusciol et al., 2013). Although we observed high $\mathrm{N}$ uptake by monocropped maize, other studies have shown that intercropping systems with forage grasses do not impair N uptake by crops (Crusciol et al., 2011; Mateus et al., 2012; Borghi et al., 2013b). Another important finding of our study is evidence of high $\mathrm{N}$ demand, as the leaf $\mathrm{N}$ concentration was below the appropriate range for maize (27$35 \mathrm{~g} \mathrm{~N} \mathrm{~kg}^{-1}$ ) (Cantarella et al., 1997) when there was no $\mathrm{N}$ application (control) for all intercropping systems and even for monocropped maize. Despite differences between intercropping systems, maize was adequately nourished in all treatments. Maize leaf concentrations of $\mathrm{P}, \mathrm{K}, \mathrm{Ca}, \mathrm{Mg}$, and $\mathrm{S}$ were within ranges considered adequate (Cantarella et al., 1997), and no nutrition problems were observed.

Although no differences in agronomic characteristics and kernel attributes were observed between monoculture and intercropping systems, greater shoot dry matter and grain yield of maize were observed in monocropped maize compared with the other treatments. The lack of competition with tropical forage grasses positively affected maize development and did not appear to limit dry matter in the early growth stages, which were characterized by high $\mathrm{N}$ uptake, implying high efficiency in intercepting photosynthetically active radiation (Amaral Filho et al., 2005; Sawyer et al., 2010). Grain yield is positively linked to dry matter accumulation and the supply of $\mathrm{N}$ and $\mathrm{C}$ to kernels (Kowles and Phillips, 1988). Previous studies have shown that intercropping maize/sorghum with palisadegrass/guineagrass did not affect grain yield or create better conditions for improving sorghum yield (Barducci et al., 2009; Borghi et al., 2013b), which may have been related to lower nutrient demand and difference in crop hybrid.

Shoot dry matter and grain yield of maize were strongly related to timing of $\mathrm{N}$ fertilizer in the cropping system. Lowest maize yield was a result of insufficient $\mathrm{N}$ supply to maize. Grass-grass rotation without $\mathrm{N}$ fertilizer addition can result in significant $\mathrm{N}$ immobilization via competition between plants and microorganisms (Schimel and Bennett, 2004; Kuzyakov and Xu, 2013). Introduction of legumes in the crop rotation can enhance soil N availability with NTS (Boddey et al., 2010). However, cultivation of forage grasses is well-established among farmers 
(Moraes et al., 2019), and C4 grass residues are more favorable in long-term protection and coverage of the soil under tropical drought conditions than C3 residues due to slower residue decomposition rate (Mateus et al., 2016; Rosolem et al., 2017).

Nitrogen fertilizer application provided an average maize yield of $8.3 \mathrm{Mg} \mathrm{ha}^{-1}$. While $\mathrm{N}$ addition increased maize yield, applying no $\mathrm{N}$ fertilizer at seeding $\left(0-100 \mathrm{~kg} \mathrm{~N} \mathrm{ha}^{-1}\right.$ applied at maize seeding and sidedressing, respectively) resulted in the lowest ears per plant, shoot dry matter, and grain yield among cropping systems receiving $\mathrm{N}$ fertilizer. Similar reductions in maize yield under delayed application of $\mathrm{N}$ fertilizer or $100 \%$ application from maize growth stages $\mathrm{V}_{6}-\mathrm{V}_{11}$ under monocropping have been reported previously (Scharf et al., 2002; Walsh et al., 2012; Muller et al., 2017). Applying the total $\mathrm{N}$ rate $\left(100 \mathrm{~kg} \mathrm{~N} \mathrm{ha}^{-1}\right)$ at sidedressing did not match optimum $\mathrm{N}$ uptake capabilities of maize, because significant $\mathrm{N}$ supply is needed during early growth stages. Adequate maize development and $\mathrm{N}$ accumulation in the plant are closely associated with metabolism of soluble protein and sugar utilization (Faleiros et al., 1996). Thus, a portion of the N fertilizer must be applied at maize seeding in this NTS with grass cover crop to achieve high yield potential. There was no difference in maize yield or forage characteristics whether application of $\mathrm{N}$ was all at maize seeding or split between seeding + sidedressing.

No difference in forage dry matter production between palisadegrass and guineagrass in the first cut may have been related to climate conditions. Low forage growth $\left(2.1 \mathrm{Mg} \mathrm{ha}^{-1}\right)$ occurred with low rainfall and temperatures between 10 and $15^{\circ} \mathrm{C}$ in early winter (Mateus et al., 2016). For the second cut, climate conditions could also explain the $23 \%$ increase in dry matter for palisadegrass compared with guineagrass. Temperature increased and stimulated the production of forage biomass, apparently with a greater effect on palisadegrass. In general, greater values of estimated animal stocking rate and estimated meat production were obtained with greater forage dry matter production.

Production of dry matter for forage of up to $4 \mathrm{Mg} \mathrm{ha}^{-1}$ is considered good (Borghi et al., 2013a) and was achieved in the second cut, even though air temperature was not ideal for forage development (i.e., $30-35^{\circ} \mathrm{C}$ ) (Costa et al., 2005). Furthermore, there was no effect of forage species in the intercropping system on CP in the first and second cuts. CP is an important parameter of nutritive value. Forage CP averaged $125 \mathrm{~g} \mathrm{~kg}^{-1}$, which was more than adequate of the $70 \mathrm{~g} \mathrm{~kg}^{-1}$ minimum required for maintaining rumen microbial efficiency in cattle (van Soest, 1994).

Forage dry matter and $\mathrm{CP}$ were at highest levels as long as $\mathrm{N}$ was applied, irrespective of timing and split $\mathrm{N}$ ratio. As expected, grasses responded to $\mathrm{N}$ fertilizer because of high $\mathrm{N}$ demand (Boddey et al., 1996; Mateus et al., 2016). The N fertilizer rate of $100 \mathrm{~kg} \mathrm{ha}^{-1}$ was considered relatively low for complex intercropping systems, but was compatible with our study's focus on finding an efficient $\mathrm{N}$ management strategy for enhancing productivity in a sustainable manner. Indeed, we observed greater maize yield and forage dry matter production compared to other studies with application rates of $<100 \mathrm{~kg} \mathrm{~N}$ ha $^{-1}$ (Mateus et al., 2016; Rosolem et al., 2017).

\section{Land Use Efficiency, Intercropping Competition Factors and Economics}

Based on observed yields, LER of maize intercropped with palisadegrass was 1.06. The LER indicates the productivity of land with intercropping relative to sole cropping on separate parcels of land. The value of 1.06 indicated that $6 \%$ less land would be needed to achieve the same yield as monocropped maize and palisadegrass separately. These results are in line with those of Meixiua et al. (2020), who found that the average LER in grass/grass (maize/wheat) intercropping was 1.59. Likewise, Pariz et al. (2017b) found that the average LER of maize/palisadegrass intercropping was 1.10. However, maize intercropping with palisadegrass without $\mathrm{N}$ application or any intercropping of maize with guineagrass resulted in LER $<1$, reflecting lower productivity of land use. Our study suggests that land saving potential for food production systems in tropical soil can only be obtained in maize-palisadegrass intercropping systems with $\mathrm{N}$ management, independent of the type of split-N application.

Maize was more competitive ( $K$ values) than the forage species; however, the dominant species in the system were forage grasses due to their aggressiveness. The $K$ values of maize were greater than those of the forage species, in agreement with Zarochentseva (2012) and possibly due to the shading effect of maize on forage grass during maize development. Our results showed that maize was able to acquire more resources in the intercropping systems even though the forage grasses were the dominant species.

For LER and $\mathrm{K}$ values of intercropping competition, addition of $\mathrm{N}$ fertilizer was necessary to enhance competitiveness of maize. Nitrogen management promoted the competitiveness of maize and forage grasses by increasing vegetative growth and providing greater capacity for utilizing limited availability of water (Marschner, 2012; Yang and Udvardi, 2018). Previous studies have shown significant differences among crops in grass/grass intercropping systems, but not among different types of N addition (O'Leary and Smith, 1999; Baxevanos et al., 2017). When a species has high competitiveness, the plant acquires more resources and occupies a superior ecological niche (Grace and Tilman, 1990). In addition, the $A$ index values were extremely low for all treatments, indicating a minimum dominance by forage grasses. These findings highlight the necessity of choosing suitable species for intercropping in maize-forage grass systems to enhance the interspecific complementarity and reduce interspecies competition (Davis and Woolley, 1993).

Intercropping is a sustainable practice of food production to improve quality of pastures and animal carrying capacity. Our results demonstrated that intercropping of tropical forage grasses with maize using NTS is a feasible option for increasing sustainability in tropical areas and can result in higher revenues for farmers due to the productive, economic, and environmental benefits of these systems. Furthermore, these systems can increase global food production from the same land area (Carvalho et al., 2010; FAO-Food and Agriculture Organization of the United Nations, 2010, 2017; Herrero et al., 2010; Franzluebbers and Stuedemann, 2014; Moraes et al., 2019). Therefore, our data indicated that maize intercropped with palisade or guineagrass is a promising approach for farmers, 
especially in the tropical regions of South America, Africa, and parts of Asia, where individuals need additional opportunities to produce food.

All treatments resulted in net profit, particularly the maize + palisadegrass and maize + guineagrass treatments with $\mathrm{N}$ management, because in addition to maize yield in the summer/autumn, farmers can use the forage dry matter production of palisade and guineagrass (Table 3) for animal fodder in the winter/spring. Thus, with maize intercropping, farmers could produce $87-218 \mathrm{~kg} \mathrm{ha}^{-1}$ meat, with net profits up to US\$ $1,600-1,800 \mathrm{ha}^{-1}$, depending of $\mathrm{N}$ management, which could add an extra US\$ 500-600 than monocropped maize. In addition, the need for soil mulch would be satisfied in planning for the next crop.

Overall, our data suggest that intercropping systems are a great option for the diversification on farm and the increase of grain and forage yields. However, these agricultural systems deserve further investigations to assess the disadvantages and impacts of $\mathrm{N}$ fertilizer. Our study raises relevant questions about which changes occur in root systems and soil fertility and microbiology in deeper soil layers, as well as the reduction in diseases and pesticide applications, in maize-forage systems receiving $\mathrm{N}$ fertilizer, and the effects of fertilizer on $\mathrm{N}$ losses to environment and $\mathrm{N}$ recovery by plants in short- and long-term of intercropping systems.

\section{CONCLUSION}

Intercropping maize with forage grasses is a promising practice to meet the dual challenges of food production and sustainable development. Since agricultural systems are region- and soilspecific, variations of intercropping systems may require different $\mathrm{N}$ fertilization recommendations. Although monocropped maize produced greatest grain yield, intercropping systems were viable in terms of balanced grain and forage yields, land use, and profitability. Estimated meat production and revenue were enhanced with intercropping of palisadegrass or guineagrass with maize. Combining animal production with crop production in an intercropping system can be advantageous not only for farmers, but also for environmental quality and biological

\section{REFERENCES}

Agegnehu, G., Ghizaw, A., and Sinebo, W. (2006). Yield performance and land-use efficiency of barley and fava bean mixed cropping in Ethiopian highlands. Eur. J. Agron. 25, 202-207. doi: 10.1016/j.eja.2006. 05.002

Agrolink. (2018). Quotations to Farming. Available online at: www.agrolink.com. br (accessed November 01, 2019).

Amaral Filho, J. P. R., Fornasieri Filho, D., Farinelli, R., and Barbosa, J. C. (2005). Row spacing, population density and nitrogen fertilization in maize. R. Bras. Ci. Solo. 29, 467-473. doi: 10.1590/S0100-06832005000300017

Anghinoni, I. (2007). "Fertilidade do solo e seu manejo em sistema plantio direto," in Fertilidade do Solo. ed R. F. Novais (Viçosa: Sociedade Brasileira de Ciência do Solo), 873-928.

Barducci, R. S., Costa, C., Crusciol, C. A. C., Borghi, E., Putarov, T. C., and Sarti, L. M. N. (2009). Production of Brachiaria brizantha and Panicum diversity of plants and soil microorganisms. However, $\mathrm{N}$ fertilizer application in these systems is still necessary for maize yields and profitability. At least a portion of total $\mathrm{N}$ input should be applied at seeding and the remainder at sidedressing of maize. Application of all $\mathrm{N}$ fertilizer at sidedressing was not a productive practice since in this study with pearl millet as previous cover crop under NTS, as it reduced maize yield and revenue. Future studies should examine biodiversity improvements in the soilplant-microorganism interactions and the negative impacts of $\mathrm{N}$ losses and nitrous oxide gasses release to the environment in the short- and long-term intercropping systems.

\section{DATA AVAILABILITY STATEMENT}

The original contributions presented in the study are included in the article/Supplementary Materials, further inquiries can be directed to the corresponding authors.

\section{AUTHOR CONTRIBUTIONS}

CACC, GM, CC, and HC designed the experiment. CACC, GM, $\mathrm{EB}$, and JC obtained and processed the data. CACC, LM, CP, AC, and AF analyzed the data. CACC, LM, and CP wrote the paper, with contribution of all co-authors. All authors confirms being contributor of this work and has approved it for publication.

\section{ACKNOWLEDGMENTS}

The authors would like to thank the São Paulo Research Foundation for financial support (FAPESP, Grant \#2003/09914-3 and Grant \#2003/01968-7). The first, eighth, and tenth authors would like to thank the National Council for Scientific and Technological Development (CNPq) for an award for excellence in research.

\section{SUPPLEMENTARY MATERIAL}

The Supplementary Material for this article can be found online at: https://www.frontiersin.org/articles/10.3389/fsufs. 2020.544853/full\#supplementary-material maximum with corn and nitrogen fertilization. Arch. Zootecn. 58, 211-222. doi: 10.4321/S0004-05922009000200006

Baxevanos, D., Tsialtas, I. T., Vlachostergios, D. N., Hadigeorgiou, I., Dorda, C., and Lithourgidis, A. (2017). Cultivar competitiveness in pea-oat intercrops under Mediterranean conditions. Field Crop. Res. 214, 94-103. doi: 10.1016/j.fcr.2017.08.024

Boddey, R. M., Jantalia, C. P., Conceicao, P. C., Zanatta, J. A., Bayer, C., Mielnizuk, J., et al. (2010). Carbon accumulation at depth in Ferralsols under zero till subtropical agriculture. Glob. Change Biol. 16, 784-795. doi: 10.1111/j.1365-2486.2009.02020.x

Boddey, R. M., Rao, I. M., and Thomas, R. J. (1996). "Nutrient cycling and environmental impact of Brachiaria pastures," in The Biology, Agronomy, and Improvement of Brachiaria. eds J. W. Miles, B. L. Maass, and C. B. do Valle (Cali: CIAT), 72-86.

Borghi, E., Crusciol, C. A. C., Mateus, G. P., Nascente, A. S., and Martins, P. O. (2013a). Intercropping time of corn and palisadegrass or guineagrass 
affecting grain yield and forage production. Crop Sci. 53, 629-636. doi: $10.2135 /$ cropsci2012.08.0469

Borghi, E., Crusciol, C. A. C., Nascente, A. S., Souza, V. V., Martins, P. O., Mateus, G. P., et al. (2013b). Sorghum grain yield, forage biomass production and revenue as affected by intercropping time. Eur. J. Agron. 51, 130-139. doi: 10.1016/j.eja.2013.08.006

Borghi, E., Crusciol, C. A. C., Trivelin, P. C. O., Nascente, A. S., Costa, C., and Mateus, G. P. (2014). Nitrogen fertilization $\left(15 \mathrm{NH}_{4} \mathrm{NO}_{3}\right)$ of palisadegrass and residual effect on subsequent no-tillage corn. $R$. Bras. Ci. Solo 38, 1457-1468. doi: 10.1590/S0100-06832014000500011

Cantarella, H., van Raij, B., and Camargo, C. E. O. (1997). "Cereals," in Lime and Fertilizer Recommendations for the State of Sao 428 Paulo. 2nd Edn, eds B. Raij, H. van Cantarella, J. A. Quaggio, and A. C. M. Furlani (Campinas: Tech. Bull. 100. Inst. Agronomico), 43-50.

Carvalho, P. C. F., Anghinoni, I., Moraes, A., Souza, E. D., Sulc, R. M., Lang, C. R., et al. (2010). Managing grazing animals to achieve nutrient cycling and soil improvement in no-till integrated systems. Nutr Cycl Agroecosyst. 88, 259-273. doi: $10.1007 / \mathrm{s} 10705-010-9360-\mathrm{x}$

CONAB (2018). Cost of Agricultural Production. Available online at: http://www. conab.gov.br/conab/Main.php?MagID=3\&MagNo=39 (accessed July 21, 2018).

Cong, W. F., Hoffland, E., Li, L., Six, J., Sun, J. H., Bao, X. G., et al. (2015). Intercropping enhances organic carbon and nitrogen in soil. Glob. Chang. Biol. 21, 1715-1726. doi: 10.1111/gcb.12738

Costa, K. A. P., Rosa, B., Oliveira, I. P., Custodio, D. P., and Silva, D. C. (2005). Effect of seasonal climate condition on the dry matter production and bromatological composition of Brachiaria brizantha cv. Marandu. Cienc. Anim. Bras. 6, 187-193.

Costa, N. R., Andreotti, M., Gameiro, R. A., Pariz, C. M., Buzetti, S., and Lopes, K. S. M. (2012). Nitrogen fertilization in the intercropping of corn with two Brachiaria species in a no tillage system. Pesqui. Agropecu. Bras. 47, 1038-1047. doi: 10.1590/S0100-204X2012000800003

Costa, N. R., Andreotti, M., Lopes, K. S. M., Yokobatake, K. L., Ferreira, J. P., Pariz, C. M., et al. (2015). Soil properties and carbon accumulation in an integrated croplivestock system under no-tillage. Rev. Bras. Ci. Solo. 39, 852-863. doi: 10.1590/01000683rbcs20140269

Crusciol, C. A. C., Mateus, G. P., Nascente, A. S., Martins, P. O., Borghi, E., and Pariz, C. M. (2012). An innovative crop-forage intercrop system: early cycle soybean cultivars and palisade grass. Agron. J. 104, 1085-1095. doi: 10.2134/agronj2012.0002

Crusciol, C. A. C., Mateus, G. P., Pariz, C. M., Borghi, E., Costa, C., and Silveira, J. P. F. (2011). Nutrition and sorghum hybrids yield with contrasting cycles intercropped with Marandu grass. Pesq. Agropec. Bras. 46, 1234-1240. doi: 10.1590/S0100-204X2011001000017

Crusciol, C. A. C., Nascente, A. S., Borghi, E., Soratto, R. P., and Martins, P. O. (2015). Improving soil fertility and crop yield in a tropical region with palisadegrass cover crops. Agron. J. 107, 2271-2280. doi: 10.2134/agronj14.0603

Crusciol, C. A. C., Nascente, A. S., Mateus, G. P., Borghi, E., Leles, E. P., and Santos, N. C. B. (2013). Effect of intercropping on yields of corn with different relative maturities and palisadegrass. Agron. J. 105, 599-606. doi: 10.2134/agronj2012.0426

Crusciol, C. A. C., Nascente, A. S., Mateus, G. P., Pariz, C. M., Martins, P. O., and Borghi, E. (2014). Intercropping soybean and palisadegrass for enhanced land use efficiency and revenue in a no till system. Eur. J. Agron. 58, 53-62. doi: 10.1016/j.eja.2014.05.001

Davis, J. H. C., and Woolley, J. N. (1993). Genotypic requirement for intercropping. Field Crop. Res. 34, 407-430. doi: 10.1016/0378-4290(93)90124-6

Derpsch, R., and Friedrich, T. (2009). "Development and current status of no-till adoption in the world," in Proceedings on CD 18th Triennial Conference of the International Soil Tillage Research Organization (Izmir: ISTRO), 15-19.

Faleiros, R. R. S., Seebauer, J. R., and Below, F. E. (1996). Nutritionally induced changes in endosperm of shrunken-1 and brittle-2 maize kernels grown in vitro. Crop Sci. 36, 947-954. doi: 10.2135/cropsci1996.0011183X0036000 $40022 x$

FAO-Food Agriculture Organization of the United Nations (2017). Integated Crop-Livestock System (ICLS). Available online at: http://www.fao.org/ agriculture/crops/core-themes/theme/spi/scpi-home/managing-ecosystems/ integrated-crop-livestock-systems/en/ (accessed November 1, 2018).
FAO-Food and Agriculture Organization of the United Nations (2010). An International Consultation on Integrated Crop-Livestock Systems for Development: The Way Forward for Sustainable Production Intensification. 64p (Integrated Crop Management, v.13). (Rome).

Fox, D. G., Tedeschi, L. O., Tylutki, T. P., Russell, J. B., van Amburgh, M. E., Chase, L. E., et al. (2004). The Cornell Net Carbohydrate and Protein System model for evaluating herd nutrition and nutrient excretion. Anim. Feed. Sci. Technol. 112, 29-78. doi: 10.1016/j.anifeedsci.2003.10.006

Franzluebbers, A. J., and Stuedemann, J. A. (2014). Crop and cattle production responses to tillage and cover crop management in an integrated croplivestock system in the southeastern. USA. Eur. J. Agron. 57, 62-70. doi: 10.1016/j.eja.2013.05.009

Garcia, C. M. P., Costa, C., Andreotti, M., Meirelles, P. R. L., Pariz, C. M., Freitas, L. A., et al. (2016). Wet and dry maize yield under intercrop culivation with marandu grass and/or dwarf pigeon pea and nutritional value of the marandu grass in succession. Austral. J. Crop. Sci. 10, 1564-1571. doi: 10.21475/ajcs.2016.10.11.PNE183

Grace, J. B., and Tilman, D. (1990). On the relationship between plant traits and competitive ability. Perspect. Plant Compet. 1, 51-65. doi: 10.1016/B978-0-12-294452-9.50008-4

Heanes, D. L. (1984). Determination of total organic-C in soils by an improved chromic acid digestion and spectrophotometric procedure. Commun. Soil Sci. Plant Anal. 10, 1191-1213. doi: 10.1080/00103628409367551

Herrero, M., Thornton, P. K., Notenbaert, A. M., Wood, S., Msangi, S., Freeman, H. A., et al. (2010). Smart investments in sustainable food production: revisiting mixed crop-livestock systems. Science 327, 822-825. doi: $10.1126 /$ science. 1183725

Himmelstein, J., Ares, A., Gallagher, D., and Myers, J. (2017). A metaanalysis of intercropping in Africa: impacts on crop yield, farmer income, and integrated pest management effects. Int. J. Agric. Sustain. 15, 1-10. doi: $10.1080 / 14735903.2016 .1242332$

Horwitz, W. (1980). Official methods of analysis of the association of analytical chemists. Assoc. Off. Anal. Chem. 60, 414-414.

Kowles, R. V., and Phillips, R. L. (1988). Endosperm development in maize. Int. Rev. Cytol. 112, 97-106. doi: 10.1016/S0074-7696(08)62007-0

Kuzyakov, Y., and Xu, X. (2013). Competition between roots and microorganisms for nitrogen: mechanisms and ecological relevance. New Phytol. 198, 656-669. doi: 10.1111/nph.12235

Li, L., Yang, S., Li, X., Zhang, F., and Christie, P. (1999). Interspecific complementary and competitive interactions between intercropped maize and faba bean. Plant Soil 212, 105-114. doi: 10.1023/A:1004656205144

Malavolta, E., Vitti, G. C., and Oliveira, S. A. (1997). Evaluation of Nutritional Status of Plant: Principles and Applications, 2nd Edn. Piracicaba: Potafos.

Marschner, H. (2012). Mineral Nutrition of Higher Plants, 3rd Edn. London: Academic Press.

Martin-Guay, M., Paquette, A., Dupras, J., and Rivest, D. (2018). The new green revolution: sustainable intensification of agriculture by intercropping. Sci. Total Environ. 615, 767-772. doi: 10.1016/j.scitotenv.2017.10.024

Mateus, G. P., Crusciol, C. A. C., Pariz, C. M., Borghi, E., Costa, C., Martello, J. M., et al. (2016). Sidedress nitrogen application rates to sorghum intercropped with tropical perennial grasses. Agron. J. 108, 433-447. doi: 10.2134/agronj2015.0236

Mateus, G. P., Crusciol, C. A. C., Pariz, C. M., Costa, N. R., Borghi, E., Costa, C., et al. (2020). Corn intercropped with tropical perennial grasses as affected by sidedress nitrogen application rates. Nutr. Cycl. Agroecosyst. 116, 223-244. doi: 10.1007/s10705-019-10040-1

Mateus, G. P., Crusciol, C. A. C., and Borghi, E. (2012). Integrated croplivestock: the new green revolution in the tropics. Pesqui Tecnol. 4, 1-5.

Mead, R., and Willey, R. W. (1980). The concepts of a land equivalent ratio' and advantages in yields from intercropping. Exp. Agric. 16, 217-228. doi: 10.1017/S0014479700010978

Meixiua, T., Fang, G., Stomph, T. J., Jing, W., Wen, Y., Lizhen, Z., et al. (2020). Dynamic process-based modelling of crop growth and competitive water extraction in relay strip intercropping: model development and application to wheat-maize intercropping. Field Crop Res. 246:107613. doi: $10.1016 /$ j.fcr.2019.107613

Mendiburu, F. D. (2015). Agricolae: Statistical Procedures for Agricultural Research. $R$ Package Version 1.2-3. Available online at: http://CRAN.R-project.org/ package $=$ agricolae 
Moraes, A., Carvalho, P. C. F., Crusciol, C. A. C., Lang, C. R., Pariz, C. M., Deiss, L., et al. (2019). Chapter 16 - integrated crop-livestock systems as a solution facing the destruction of Pampa and Cerrado biomes in South America by intensive monoculture systems. Agroecosyst. Div. 1, 257-273. doi: 10.1016/B978-0-12-811050-8.00016-9

Muller, S. M., Camberato, J. J., Messina, C., Shanahan, J., Zhang, H., and Vyn, T. J. (2017). Late-split nitrogen applications increased maize plant nitrogen recovery but not yield under moderate to high nitrogen rates. Agron. J. 109, 2689-2699. doi: 10.2134/agronj2017.05.0282

Murphy, J., and Riley, J. P. (1962). A modified single solution method for the determination of phosphate in natural waters. Anal. Chim. Acta 27, 31-36. doi: 10.1016/S0003-2670(00)88444-5

O'Leary, N., and Smith, M. E. (1999). Breeding corn for adaptation to two diverse intercropping companions. Am. J. Altern. Agric. 14, 158-164. doi: 10.1017/S0889189300008328

Pariz, C. M., Andreotti, M., Azenha, M. V., Bergamaschine, A. F., Mello, L. M. M., and Lima, R. C. (2011). Corn grain yield and dry mass of Brachiaria intercrops in the crop-livestock integration system. Cienc. Rural 41, 875-882. doi: 10.1590/S0103-84782011000500023

Pariz, C. M., Andreotti, M., Tarsitano, M. A. A., Bergamaschine, A. F., Buzetti, S., and Chioderolli, C. A. (2009). Technical and economical performance of corn intercropped with Panicum and Brachiaria forage in crop-livestock integration system. Pesq. Agropec. Trop. 39, 360-370.

Pariz, C. M., Costa, C., Crusciol, C. A. C., Castilhos, A. M., Meirelles, P. R. L., Roça, R. O., et al. (2017a). Lamb production responses to grass grazing in a companion crop system with corn silage and oversowing of yellow oat in a tropical region. Agr. Syst. 151, 1-11. doi: 10.1016/j.agsy.2016. 11.004

Pariz, C. M., Costa, C., Crusciol, C. A. C., Meirelles, P. R. L., Castilhos, A. M., Andreotti, M., et al. (2016). Production and soil responses to intercropping of forage grasses with corn and soybean silage. Agron. J. 108, 2541-2553. doi: 10.2134/agronj2016.02.0082

Pariz, C. M., Costa, C., Crusciol, C. A. C., Meirelles, P. R. L., Castilhos, A. M., Andreotti, M., et al. (2017b). Production, nutrient cycling and soil compaction to grazing of grass companion cropping with maize and soybean. Nutr. Cycl. Agroecosyst. 108, 35-54. doi: 10.1007/s10705-016-9821-y

Rosolem, C. A., Ritz, K., Cantarella, H., Galdos, M. V., Hawkesford, M. J., Whalley, W. R., et al. (2017). Enhanced plant rooting and crop system management for improved $\mathrm{N}$ use efficiency. Adv. Agron. 146, 205-239. doi: 10.1016/bs.agron.2017.07.002

Sawyer, J. E., Pedersen, P., Barker, D. W., Diaz, D. A. R., and Albrecht, L. (2010). Intercropping corn and kura clover: response to nitrogen fertilization. Agron. J. 102, 568-574. doi: 10.2134/agronj2009.0392

Scharf, P. C., Wiebold, W. J., and Lory, J. A. (2002). Corn yield response to nitrogen fertilizer timing and deficiency level. Agron. J. 94, 435-441. doi: 10.2134/agronj2002.4350
Schimel, J. P., and Bennett, J. (2004). Nitrogen mineralization: challenges of a changing paradigm. Ecology 85, 591-602. doi: 10.1890/03-8002

Sulc, R. M., and Tracy, B. F. (2007). Integrated crop-livestock systems in the U.S. Corn Belt. Agron. J. 99, 335-345. doi: 10.2134/agronj2006.0086

Takim, F. O. (2012). Advantages of maize-cowpea intercropping over sole cropping through competition indices. J. Agric. Biodivers. Res. 1, 53-59.

Tracy, B. F., and Zhang, Y. (2008). Soil compaction, corn yield response, and soil nutrient pool dynamics within an integrated crop-livestock system in Illinois. Crop Sci. 48, 1211-1218. doi: 10.2135/cropsci2007.07.0390

United States Department of Agriculture (USDA) (2014). Keys to Soil Taxonomy, 12th Edn. Washington, DC, 372.

van Raij, B., Andrade, J. C., Cantarella, H., and Quaggio, J. A. (2001). Chemical Analysis for Fertility Evaluation of Tropical Soils. Campinas: Instituto Agronômico (IAC).

van Soest, P. J. (1994). Nutritional Ecology of the Ruminant, 2nd Edn. Ithaca: Cornell University Press.

Wahla, I. H., Ahmad, R., Ahmad, A., and Jabbar, A. (2009). Competitive functions of components crops in some barley based intercropping systems. Int. J. Agric. Biol. 11, 1560-853011.

Walsh, O., Raun, W., Klatt, A., and Solie, J. (2012). Effect of delayed nitrogen fertilization on maize (Zea mays L.) grain yields and nitrogen use efficiency. J. Plant Nutr. 35, 538-555. doi: 10.1080/01904167.2012.644373

Yang, J., and Udvardi, M. (2018). Senescence and nitrogen use efficiency in perennial grasses for forage and biofuel production. J. Exp. Bot. 69, 855-865. doi: $10.1093 / \mathrm{jxb} / \mathrm{erx} 241$

Zarochentseva, O. (2012). Adaptation of Methodology Calculation Relative Crowding Coefficient for Evaluation Competition of Tree Species in Polyculture. Ukraine: Yuriy Fedkovich Chernivtsi National University, 1-2.

Zhang, G., Yang, Z., and Dong, S. (2011). Interspecific competitiveness affects the total biomass yield in an alfalfa and corn intercropping system. Field Crop. Res. 124, 66-73. doi: 10.1016/j.fcr.2011.06.006

Conflict of Interest: EB was employed by the company Brazilian Agricultural Research Corporation (EMBRAPA), Brazil.

The remaining authors declare that the research was conducted in the absence of any commercial or financial relationships that could be construed as a potential conflict of interest.

Copyright (c) 2020 Crusciol, Mateus, Momesso, Pariz, Castilhos, Calonego, Borghi, Costa, Franzluebbers and Cantarella. This is an open-access article distributed under the terms of the Creative Commons Attribution License (CC BY). The use, distribution or reproduction in other forums is permitted, provided the original author(s) and the copyright owner(s) are credited and that the original publication in this journal is cited, in accordance with accepted academic practice. No use, distribution or reproduction is permitted which does not comply with these terms. 